\title{
Proposed changes in systematics and status of some genera of Tachydromiini (Diptera: Hybotidae: Tachydromiinae), with description of a new species of Tachypeza Meigen from Canada and USA
}

\section{Изменения в систематике и статусе некоторых родов Tachydromiini (Diptera: Hybotidae: Tachydromiinae), с описанием нового вида Tacbypeza Meigen из Канады и США}

\author{
I.V. Shamshev ${ }^{1}$, P. Grootaert ${ }^{2}$ \\ И.В. Шамшев ${ }^{1}$, П. Гротерт ${ }^{2}$
}

\footnotetext{
${ }^{1}$ Zoological Institute, Russian Academy of Sciences, Universitetskaya nab. 1, St. Petersburg 199034, Russia. Corresponding author, E-mail: shamshev@mail.ru

1 Зоологический институт РАН, Университетская наб. 1, С.-Петербург 199034, Россия.

${ }^{2}$ Royal Belgian Institute of Natural Sciences, Rue Vautier 29, B-1000, Brussels, Belgium. E-mail: Patrick.Grootaert@naturalsciences.be
}

KEYWORDS. Diptera, Hybotidae, Tachydromia, Tachypeza, Ariasella, Pieltainia, synonyms, new species.

КЛЮЧЕВЫЕ СЛОВА. Diptera, Hybotidae, Tachydromia, Tachypeza, Ariasella, Pieltainia, synonyms, new species.

ABSTRACT. A more precise definition of the genus Tachypeza Meigen, 1830 (Diptera: Hybotidae: Tachydromiinae) is discussed. It is suggested to transfer to Tachypeza the following 13 species assigned earlier to the genus Tachydromia Meigen, 1803: Tachypeza annamensis (Grootaert et Shamshev, 2009), comb.n.; T. australiensis (Grootaert et Shamshev, 2011), comb.n.; T. bickeli (Grootaert et Shamshev, 2011), comb.n.; T. corticola (Grootaert et Shamshev, 2011), comb.n.; T. luang (Shamshev et Grootaert, 2005), comb.n.; T. malaysiensis (Shamshev et Grootaert, 2009), comb.n.; T. nowendociensis (Grootaert et Shamshev, 2011), comb.n.; T. ocellata (Shamshev et Grootaert, 2008), comb.n.; T. pahangiensis (Shamshev et Grootaert, 2009), comb.n.; T. phanensis (Shamshev et Grootaert, 2008), comb.n.; T. phu (Shamshev et Grootaert, 2008), comb.n.; T. sachem (Melander, 1928), comb.n.; T. stuckenbergi (Shamshev et Grootaert, 2010), comb.n.; T. tigeri (Shamshev et Grootaert, 2008), comb.n. A new species of Tachypeza, T. cummingi sp. n., is described from Canada and the USA. Currently, Tachypeza includes 45 species and the genus is formally recorded for the first time from Australasian (5 species), Afrotropical (1 species) and Neotropical (1 species) Realms. Main phylogenetic lineages within Tachypeza are provisionally discussed. A check-list of Tachypeza of the world is provided. Genera Ariasella Gil, 1923, syn. n., and Piel- tainia Arias, 1919, syn. n., are placed in synonymy to Tachydromia, with the following new combinations: Tachydromia iberica (Arias, 1919), comb.n.; T. lusitanica (Grootaert, Shamshev et Andrade, 2009), comb.n.; T. pandellei (Séguy, 1941), comb.n.; T. pieltaini (Gil, 1936), comb.n.; T. semiaptera (Gil, 1923), comb.n. Currently, the genus Tachydromia includes 108 species. Main phylogenetic lineages within Tachydromia are provisionally discussed, with two newly recognised groups of species.

РЕЗЮМЕ. Обсуждается более точная дефиниция рода Tachypeza Meigen, 1830 (Diptera: Hybotidae: Tachydromiinae). Предлагается перенести в Tachyреza следующие 13 видов, помещённые ранее в род Tachydromia Meigen, 1803: Tachypeza annamensis (Grootaert et Shamshev, 2009), comb.n.; T. australiensis (Grootaert et Shamshev, 2011), comb.n.; T. bickeli (Grootaert et Shamshev, 2011), comb.n.; T. corticola (Grootaert et Shamshev, 2011), comb.n.; T. luang (Shamshev et Grootaert, 2005), comb.n.; T. malaysiensis (Shamshev et Grootaert, 2009), comb.n.; $T$. nowendociensis (Grootaert et Shamshev, 2011), comb.n.; T. ocellata (Shamshev et Grootaert, 2008), comb.n.; T. pahangiensis (Shamshev et Grootaert, 2009), comb.n.; T. phanensis (Shamshev et Grootaert, 2008), comb.n.; T. phu (Shamshev et Grootaert, 2008), comb.n.; T. sachem

How to cite this article: Shamshev I.V., Grootaert P. 2018. Proposed changes in systematics and status of some genera of Tachydromiini (Diptera: Hybotidae: Tachydromiinae), with description of a new species of Tachypeza Meigen from Canada and USA // Russian Entomol. J. Vol.27. No.4. P.425-434. doi: 10.15298/rusentj.27.4.10 
(Melander, 1928), comb.n.; T. stuckenbergi (Shamshev et Grootaert, 2010), comb.n.; T. tigeri (Shamshev et Grootaert, 2008), comb.n. Новый вид Tachypeza, T. cummingi sp. n., описывается из Канады и США. В настоящее время Tachypeza включает 45 видов и формально указывается впервые для Австралоазиатского (5 видов), Афротропического (1 вид) и Неотропического царств (1 вид). Предварительно обсуждаются основные филогенетические линии внутри Tachypeza. Представлен список видов Tachypeza мира. Роды Ariasella Gil, 1923, syn. n., и Pieltainia Arias, 1919, syn. n., рассматриваются в качестве синонимов рода Tachydromia, со следующими новыми комбинациями: Tachydromia iberica (Arias, 1919), comb.n.; T. lusitanica (Grootaert, Shamshev et Andrade, 2009), comb.n.; T. pandellei (Séguy, 1941), comb.n.; T. pieltaini (Gil, 1936), comb.n.; T. semiaptera (Gil, 1923), comb.n. В настоящее время Tachydromia включает 108 видов. Предварительно обсуждаются основные филогенетические линии внутри Tachydromia, выделены две новые группы видов.

\section{Introduction}

The Tachydromiinae is a very diverse subfamily in the family Hybotidae comprising quite small (1.0 to 5.0 $\mathrm{mm}$ ) predatory flies that are generally seen running on leaves of vegetation but also occur under many other conditions including tree-trunks, stones, sandy biotopes, etc. The Tachydromiinae are worldwide in distribution and rich in species. Currently the subfamily includes about 1200 species [Grootaert, Shamshev, 2012]. The subfamily Tachydromiinae is clearly monophyletic and this group is generally characterized by the apomorphic loss of vein $\mathrm{M}_{2}$ and cell $d m$ (due to the loss of $d m-c u$ crossvein). Additionally, tachydromiines have no wing pterostigma and pseudotracheae as well as they possess some distinctive features of the male terminalia including simple apex of the phallus and the ejaculatory apodeme not fused to phallus base [Sinclair, Cumming, 2006]. Also, nucleotide data indicated robust support for the Tachydromiinae [Moulton, Wiegmann, 2007; Wahlberg, Johanson, 2018]. Chvála [1975a] presented a cladogram of the phylogenetic relationships within the subfamily Tachydromiinae and his pattern is generally accepted. The subfamily is divided into three tribes, namely Symballophthalmini Sinclair et Cumming 2006, Tachydromiini Meigen, 1822 and Drapetini Collin, 1961 [Sinclair, Cumming, 2006].

The Tachydromiini is defined by the following apomorphies: presence of a precoxal bridge and a weakened vein $\mathrm{A}_{1}$ (anal vein or $\mathrm{CuA}+\mathrm{CuP}$ by authors) [Sinclair, Cumming 2006: 79]. The tribe Tachydromiini includes the following seven recent genera: Ariasella Gil, 1923, Dysaletria Loew, 1864, Pieltainia Arias, 1919, Platypalpus Macquart, 1827, Tachydromia Meigen, 1803, Tachyempis Melander, 1928 and Tachypeza Meigen, 1830 [Shamshev, Grootaert, 2012]. The genera Platypalpus and Dysaletria are quite well de- fined [Chvála, 1975b; Grootaert, Chvála, 1992]. However, a definition of remaining genera are rough, especially, in the world context. In our paper we discuss more accurate distinguishing genera Tachydromia and Tachypeza as well as the taxonomic status of the genera Ariasella and Pieltainia. A new species of Tachypeza is described from Canada and the USA.

\section{Materials and methods}

Our study is actually based on Tachydromiinae materials obtained from many museums of the world, they have been listed in our previous papers (e.g., Grootaert, Shamshev, 2009, 2011; Shamshev, Grootaert, 2005, 2009, 2010, 2012). Specimens noted in this paper are deposited in Canadian National Collection of Insects and Arachnids, Ottawa, Canada (CNC), Muséum national d'Histoire naturelle, Paris, France (MNHN), the Royal Belgian Institute of Natural Sciences, Brussels, Belgium (RBINS) and the Zoological Institute of Russian Academy of Sciences, St. Petersburg, Russia (ZISP). The terminology and descriptive format used in the description of the new species follow Grootaert \& Shamshev [2012]. To facilitate observations, the terminalia were macerated in cold $10 \% \mathrm{KOH}$ and hot $85 \%$ lactic acid and immersed in glycerine. Drawings of morphological features were made with a camera lucida attached to a compound microscope. In descriptions, the right and left side of the male terminalia are based on the unrotated position viewed posteriorly, such that in the illustrations the right surstylus appears on the reader's left side and vice versa. Male terminalia are figured in their unrotated position. Photos were produced using a Nikon SMZ 1500 stereomicroscope equipped with Nikon D700 digital SLR camera and were aligned and stacked using the Helicon Focus 5.3.14 software. During the process of identification all species were numbered (e.g., NA-8). These MS references are cited in the paragraphs of the material examined.

\section{Systematics}

Class Insecta Linnaeus, 1758

Order Diptera Linnaeus, 1758

Suborder Brachycera Macquart, 1834

Superfamily Empidoidea Latreille, 1804

Family Hybotidae Meigen, 1820

Subfamily Tachydromiinae Meigen, 1822

Notes on systematics of Tachydromia and Tachypeza

The genus Tachydromia (type species Musca cimecoides Fabricius, 1779 [= Tachydromia connexa Meigen, 1822]) is worldwide in distribution and currently includes 121 species: Palaearctic - 80, Nearctic - 15, Afrotropics - 4, Australasia - 6, Neotropical - 3 and Oriental - 18 [Grootaert, Shamshev, 2009; Shamshev, Grootaert, 2005, 2008, 2009; Stark, Doczkal, 2017].

The genus Tachypeza (type species Tachydromia nervosa Meigen, 1822 [= Tachydromia nubila Meigen, 1804]) includes 31 species known only from the Palaearctic (11), Nearctic (16) and Oriental (4) Realms. 
It is deeply rooted in keys that Tachypeza is distinguished from Tachydromia by the presence of the vein $\mathrm{CuA}_{2}$ (or $\mathrm{CuA}$ by authors) [e.g., Chvála, 1975a: 36, or more recently Cumming, Sinclair, 2009: 655; Grootaert, Shamshev, 2012: 13] However, this is not quite so. The vein $\mathrm{CuA}_{2}$ is very unstable in T. fuscipennis (Fallén, 1815) and T. tanaisense Kovalev, 1975 [Collin, 1961; Shamshev, unpublished data], being often faintly indicated or completely absent. Collin [1961: 72] is, probably, the only who noted that the most important difference between Tachydromia and Tachypeza is the position of the ocellar triangle, which in Tachydromia is "nearer the upper hind corner of the eyes, and the vertex behind the ocellar triangle is wider than the frons just in front of the front ocellus, not narrower as in Tachypeza". We would describe this feature in somewhat different terms (more neutral): eyes with upper margins extending far beyond ocellar tubercle, strongly approximated and parallel behind ocellar tubercle (distance between them usually slightly narrower than frons) (Tachypeza [e.g., Chvála, 1975a: 216, figs 519-521; fig. 2 in present paper]) versus eyes with upper margins on level of ocellar tubercle, more or less lateroclinate (Tachydromia) [e.g. Chvála, 1975a: 21, fig. 7]. It should be noted that the discussed character is absent in all recent and extant genera of Tachydromiini and, thus, is a synapomorphy of the genus Tachypeza.

Shamshev and Grootaert [2005, 2008] distinguished the Tachydromia luang group to include five species described by them from Thailand. Later, we added to this group two new species collected in Malaysia [Shamshev, Grootaert, 2009], one new species from Vietnam [Grootaert, Shamshev, 2009], four new species from Australia [Grootaert, Shamshev, 2011] and one new species from the Afrotropics [Shamshev, Grootaert, 2010; Grootaert et al., 2015] (totally 13). The group was distinguished from other species groups of Tachydromia by the following two characters: palpus with a subapical, very long (usually much longer than palpus), strong, black seta and right epandrial lamella of the male terminalia with a ventral, lobe-like projection (absent in Australian species). We placed all these species in Tachydromia following the traditional definition of the genus that has been discussed above (i.e., vein $\mathrm{CuA}_{2}$ absent). However, a critical re-examination of them showed, that species of the Tachydromia luang group are actually closer to Tachype$z a$ primarily sharing an apomorphic structure of the head. This conclusion was supported by molecular analysis of the COI gene [Nagy et al., 2013] and confirmed by combining COI, $18 \mathrm{~S}$ fragments and PGD [J. Mortelmans, unpublished data].

Consequently, we transfer to the genus Tachypeza all the following 12 species assigned earlier to the Tachydromia luang group: T. annamensis (Grootaert et Shamshev, 2009), comb.n.; T. australiensis (Grootaert et Shamshev, 2011), comb.n.; T. bickeli (Grootaert et Shamshev, 2011), comb.n.; T. corticola (Grootaert et Shamshev, 2011), comb.n.; T. luang (Shamshev et Grootaert, 2005), comb.n.; T. malaysiensis (Shamshev et Grootaert, 2009), comb.n.; T. nowendociensis (Grootaert et Shamshev, 2011), comb.n.; T. ocellata (Shamshev et Grootaert, 2008), comb.n.; T. pahangiensis (Shamshev et Grootaert, 2009), comb.n.; T. phanensis (Shamshev et Grootaert, 2008), comb.n.; T. phu (Shamshev et Grootaert, 2008), comb.n.; T. stuckenbergi (Shamshev et Grootaert, 2010), comb.n.; T. tigeri (Shamshev et Grootaert, 2008), comb.n. Additionally, we place in Tachypeza one species of Tachydromia described by Melander [1928] from Costa Rica, T. sachem (Melander, 1928), comb.n. (see below for discussion) and describe below a new species of Tachype$z a$ from Canada and the USA.

Proposed changes in systematic position of these species amplify strongly the pattern of the world distribution of
Tachypeza. Currently, the genus includes 45 species. Tachypeza is formally recorded for the first time from Australasian, Afrotropical and Neotropical Realms. In the Australasian Realm Tachypeza is represented by four species [Grootaert, Shamshev, 2011], in the Afrotropical and Neotropical Realms by one species each - T. stuckenbergi and T. sachem, respectively [Shamshev, Grootaert, 2010]. The Oriental Realm includes 12 species. To summarize, Tachypeza is known almost exclusively from the northern hemisphere, only four species occur in Australia.

The genus Tachypeza has never been divided into species groups. Provisionally, the following groups of species (phylogenetic lineages) could be outlined. The $T$. luang group includes all species transferred from Tachydromia (see above), T. fuscipennis (Fallén, 1815), T. tanaisense Kovalev, 1975 (both Palaearctic) and T. vriesi Grootaert et Shamshev, 2009 (Vietnam). This group is primarily supported by the presence of very long subapical seta on the palpus (e.g., Grootaert, Shamshev, 2012: 149, fig. 245). The group is most diverse in the Oriental Realm, with 9 described species. Oriental, single Afrotropical and two Palaearctic species of the T. luang group belong to a separate complex supported by the presence of a subglobular ventral lobe on the right epandrial lamella of the male terminalia (e.g., Shamshev, Grootaert, 2005: 116, fig. 14). A complex of four species known from Australia share an apomorphic fusion of the left surstylus with the epandrium (e.g., Grootaert, Shamshev, 2011: 105, fig. 1d). Tachypeza nubila and, probably, T. hispanica Chvála, 1981 constitute another lineage within Tachypeza, which is closely related to the $T$. luang group. All remaining Palaearctic species of Tachypeza belong to a separate group that, probably, also includes some North American species. A new species described below reveals quite clear relationships between Tachypeza of Nearctic and Oriental Realms. Final decisions on the monophyly and relationships of these groups must wait until the North American species are fully analysed.

After changes proposed here the genus Tachydromia includes 108 species (Palaearctic - 80, Nearctic - 15, Afrotropics - 3, Australasia - 2, Neotropical - 2 and Oriental - 10)

Chvála [1970, 1975a] divided Tachydromia into eight groups of species (terricola, ornatipes, arrogans, interrupta, connexa, calcanea, annulimana, punctifera groups), Shamshev \& Grootaert [2005, 2008] distinguished the T. luang group (see above), and Stark \& Doczkal [2017] very recently added the T. acklandi group. Provisionally, we would outline the following groups of species (phylogenetic lineages) of Tachydromia.

The $T$. papuana lineage is a newly recognised group of Tachydromia uniting six species known only from the Oriental (T. achterbergi Grootaert et Shamshev, 2009; T. doi Shamshev et Grootaert, 2008; T. mengyangensis Grootaert, Yang et Shamshev, 2008; T. monocercus Shamshev et Grootaert, 2008) and Australasian (T. carnarvonensis Grootaert et Shamshev, 2011; T. papuana Grootaert, 1987) Realms. The group is primarily supported by a remarkably long presutural dorsocentral seta and apomorphic reduction of left cercus.

The $T$. arrogans lineage (arrogans + calcanea + interrupta + punctifera groups sensu Chvála, 1975a) is the largest group of Tachydromia in number of species, it has a worldwide distribution. Within this lineage, species of the $T$. punctifera group may constitute a separate unit primarily sharing bicoloured palpus of the male. The group includes at least four species and has a Holarctic distribution.

The $T$. fuscinervis lineage is a newly recognised group of Tachydromia uniting at least six Palaearctic (mostly in Asiatic part) and four Nearctic species. The group is primarily supported 
by the presence of a tuft of flattened setae on the ventral face of the right epandrial lamella of the male terminalia (e.g., Chvála, 1970: 436, fig. 15; Shamshev, 1994a: 34, fig. 1). Chvála [1970] placed some species of this lineage in his T. terricola group.

The T. connexa group is a distinct lineage of Tachydromia primarily supported by the presence of modified pregenital segments of the male. Also, this lineage includes species of the T. acklandi group sensu Stark \& Doczkal [2017], which constitutes a separate unit sharing modified setation of the palpus.

The $T$. terricola lineage includes here only two of several species placed by Chvála [1970] in this group (T. terricola Zetterstedt, 1819 and T. sabulosa Meigen, 1830). In total, the lineage unites four species known from the Palaearctic and three species from the Oriental Realms (T. guangdongensis Yang et Grootaert, 2006; T. longyuwanensis Saigusa et Yang, 2003; T. terricoloides Shamshev et Grootaert, 2005).

The T. annulimana lineage (sensu Chvála, 1970) is a distinct group of Tachydromia including 6 species known only from the Palaearctic.

\section{Notes on the status of Ariasella and Pieltainia}

Arias [1919] erected the new genus Pieltainia to include the single species $P$. iberica collected from Spain (Huelva Province). He distinguished Pieltainia from Tachydromia and Tachypeza by the complete reduction of wings and halteres. The genus remains monotypic until now.

Gil [1923] erected the new genus Ariasella to include the single species A. semiaptera collected from Spain (Avila Province). As main distinguishing feature of Ariasella he noted reduced wings, which in A. semiaptera are stalk-like in the male and squamiform in the female. Later Gil [1936] described a second species of this genus (A. pieltaini, known after female only) again taken from Spain. Séguy [1941] found one more Ariasella species (A. pandellei) from HautesPyrénées (France). Finally, quite recently Grootaert et al. [2009] described a new species (A. lusitanica) from Portugal. Additionally, Andrade [2011] published detailed observations on different aspects of the life history of this species.

Grootaert and Shamshev [2008] summarized cases of brachyptery (or even aptery) in Hybotidae, where it is especially common in the subfamily Tachydromiinae. Additionally, this phenomenon is known in some species of Baeodromia Cumming, 2007 and found recently in Platypalpus apterus Freitas-Silva et Ale-Rocha, 2013 described from Brazil [Cumming, 2007; Freitas-Silva, Ale-Rocha, 2013]. Within the genus Tachydromia intermediate species between those with reduced and non-reduced wings are present [Shamshev, 1994b; Stark, 1996; Plant, Deeming, 2006; Stark, Doczkal, 2017]. It is clear that this feature has no phylogenetic value and was likely to develop as an adaptation to concrete ecological conditions and behaviour, when the stalks (reduced wings) are used for signalling to the female. To summarize, there is no morphological hiatus between Ariasella, Pieltain$i a$ and Tachydromia. This conclusion was supported by molecular analysis of the COI gene [Nagy et al., 2013] and confirmed by combining COI, $18 \mathrm{~S}$ fragments and PGD [J. Mortelmans, unpublished data].

So, we place Pieltainia, syn. n., and Ariasella, syn. n., in synonymy to Tachydromia, with the following new combinations: Tachydromia iberica (Arias, 1919), comb.n.; T. lusitanica (Grootaert, Shamshev et Andrade, 2009), comb.n.; T. pandellei (Séguy, 1941), comb.n.; T. pieltaini (Gil, 1936), comb.n.; T. semiaptera (Gil, 1923), comb.n. Within Tachydromia, all these species could be associated with the $T$. arrogans group.

\section{Description of new species and new records}

\section{Tachydromia semiaptera (Gil), comb.n.}

Ariasella semiaptera Gil, 1923: 153. Type-locality: Valle de Iruelas, provincia de Avila (Spain)

MATERIAL EXAMINED. $30^{7} \sigma^{7}, 3$ 우, SPAIN: Jaén, Cazorla Nat. Park, 8.05.1988, L. Masner, ss.; Ariasella semiaptera Gil, det. J.M. Cumming (CNC).

REMARKS. The species remains known only from Spain, where it is probably quite widely distributed.

DISTRIBUTION. PALAEARCTIC: Spain.

\section{Tachypeza cummingi Shamshev et Grootaert, sp. n. Figs 1-6.}

TYPE MATERIAL. Holotype — $0^{7}$, labelled: CANADA: “Ont. [= Ontario]: Ottawa / 30.v.1992 / J.M. Cumming"; "Holotype [red label]; "Tachypeza / cummingi sp. nov. / Shamshev et Grootaert" (CNC) [NA-8].

Paratypes: CANADA: Alberta: $30^{7} \sigma^{\top}, 1$, , Valleyview, 6.vi.1961, A.R. Brooks (CNC); 1 male, Grande Prairie, 11.vi.1961, A.R. Brooks (CNC); 4 Oᄋ, Kananaskis, For. Exp. Stn. Seebe, 25.vi.1962, W.R.M. Mason (CNC); $1 \mathrm{O}^{7}$, Jumping Pd. Cr., 20 mi. W Calgary, 28.vi.1962, W.R.M. Mason (CNC); $10^{7}, 40 \mathrm{~km} \mathrm{~N}$ of Colemann, 27.05-3.vi.1980, D. Williams (CNC); $1 \mathrm{O}^{\top}$, Edmonton, U. of A. Ecol. Res., malaise, spruce/aspen, 29.05-5.vi.1986, B.V. Brown (CNC). Manitoba: 3 $\sigma^{7} \sigma^{7}, 1$ ㅇ, Aweme, 29.v.1923, R.M. White (CNC); 20 o $^{7} \sigma^{7}, 13$ 우, 2 mi. W. Stockton, on trunk of aspen, 26.v.1958, J.F. McAlpine (1 $\sigma^{7}, 1$ o in RBINS, $1 \sigma^{7}$ in ZISP, others in CNC). Ontario: $4 \sigma^{7} \sigma^{7}, 6$ Osgood, on trunk of aspen, 16.v.1951, J.F. McAlpine (CNC); 1 , Port Severn, 3 mi. N Black spruce bog, 18.v.1959 (CNC); 6 o $^{7} \sigma^{7}, 1$ ㅇ, Bell's Corners, 19.v.1965, K. Skattler (CNC); 3 우, Mer Bleu, 5 mi. E. Ottawa, Malaise trap, 7.vi.1966, D.D. Munroe (CNC); 1 , same data, 9.vi.1966, D.D. Munroe (CNC); 1 \%, same data, 13.vi.1966, D.D. Munroe (CNC); 1 , same data, 15.vi.1966, D.D. Munroe (CNC); 1 , same data, 27.vi.1966, D.D. Munroe (CNC); $1 \mathrm{O}^{7}, 7$ mi. E. Griffith, 5.vi.1988, B.E. Cooper (CNC); 1 \%, Ottawa, 22.v.1992, J.M. Cumming $(\mathrm{CNC})$. Northwest Territories: $1 \sigma^{7}, 1$, Rd. nr. Stock Lake, ex. malaise trap, 14.vi.1966, G.E. Shewell (1 $\mathrm{O}^{7}$ in CNC, 1 क in ZISP); 1 female, Wrigley, 14.vi.1969, G.E. Shewell (CNC). Saskatchewan: 1 $\sigma^{7}$, Indian Head, 31.v.1931, K.E. Stewart (CNC); Yukon: $1 \mathrm{O}^{7}$, km 155 Dempster Hwy, 2.vii.1982, D.M. Wood (CNC). USA: Michigan: 19 , Midland C., 21-31.v.1961, R.R. Dreisbach (CNC).

DIAGNOSIS. A species of Tachypeza lacking vein $\mathrm{CuA}_{2}$; palpus pale, silvery white pubescent; prothoracic sclerites and mesonotum greyish pollinose, mesopleuron shiny; 1 pair of spine-like prescutellar dorsocentrals and 1 pair of similar wide apart scutellars; wing largely brownish infuscate, with hyaline band near base. Male: fore femur with brown rounded ventral spot near base; mid femur with small depression near base ventrally.

DESCRIPTION. Male (Fig. 1). Length: body 2.2-2.5 $\mathrm{mm}$, wing 2.1-2.3 mm. Head black. Eyes (Fig. 2) with upper margins extending far beyond ocellar tubercle, strongly approximated behind ocellar tubercle leaving very narrow parallel-sided vertex (slightly narrower than frons). Occiput uniformly greyish pollinose; 2 minute black closely set verticals, 4 moderately long black strong setae on middle portion behind verticals, some short pale setae around neck, row of minute postoculars, numerous silvery white setae behind mouth-opening and laterally. Ocellar tubercle greyish pollinose; 2 minute ocellars. Frons uniformly greyish pollinose, almost parallelsided, slightly broadened below ocellar tubercle, rather narrow, above antennae 2.0-2.5 times as broad as anterior ocellus. Antenna with scape and pedicel yellow, postpedicel and stylus brownish yellow; postpedicel conical, scarcely pubescent; stylus apical, nearly 7.0 times as long as postpedicel. Proboscis brown, somewhat elongate. Palpus unmodified, narrowed apically, nearly 1.5 times shorter than proboscis, pale, silvery 


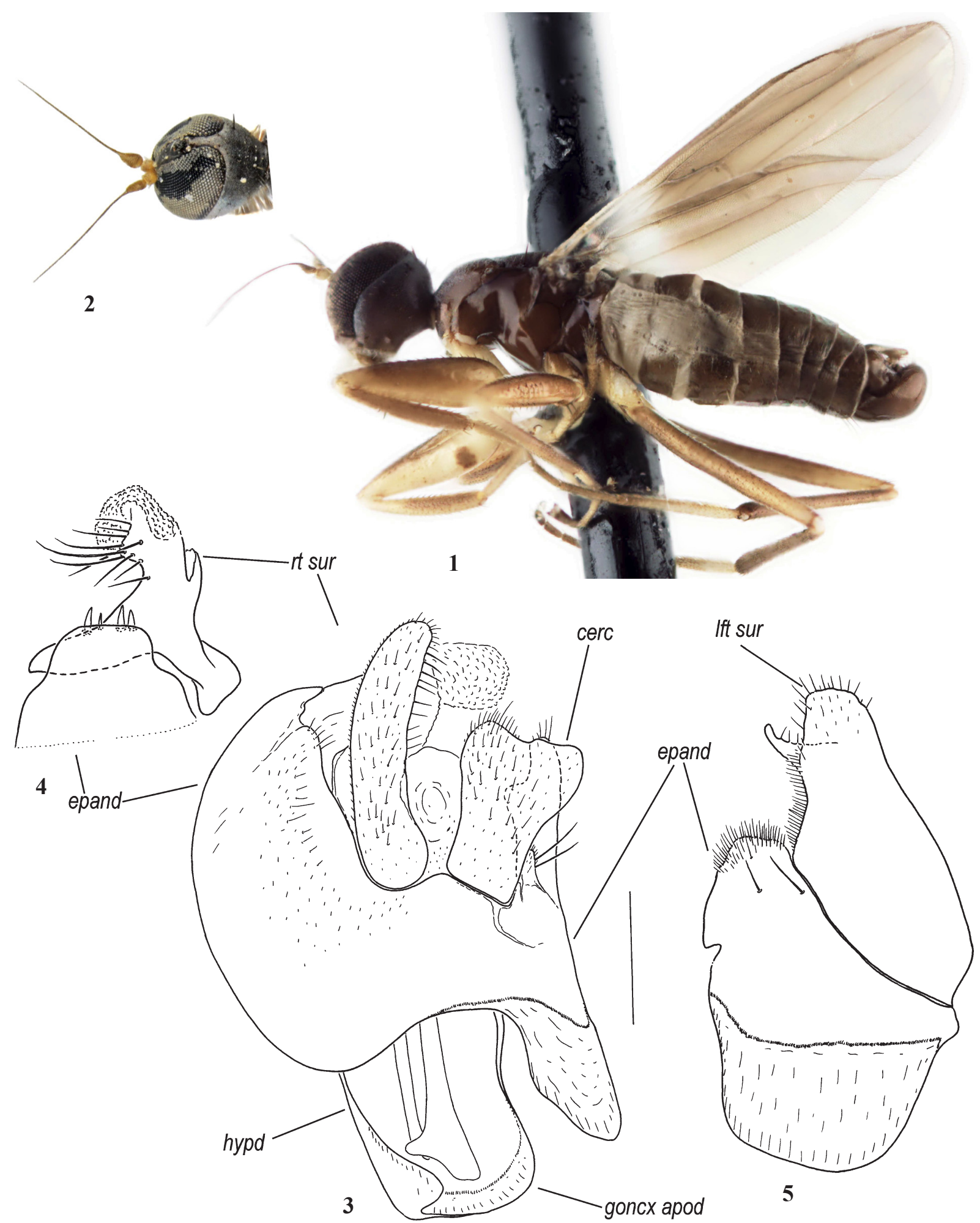

Figs 1-5. Tachypeza cummingi sp. n., $\sigma^{7}$, paratype. 1 - habitus, lateral view; 2 - head, dorsal view; 3 - terminalia, dorsal view; 4 apical part of right epandrial lamella and right surstylus, lateral view; 5 - left epandrial lamella and left surstylus, lateral view. Abbreviations: cerc - cercus; epand — epandrium; goncx apod — gonocoxal apodeme; hypd — hypandrium; lft sur — left surstylus; rt sur — right surstylus. Scale bar: $0.1 \mathrm{~mm}$

Рис. 1-5. Tachypeza cummingi sp. n., О', паратип. 1 - габитус, сбоку; 2 - голова, сверху; 3 - терминалии, сверху; 4 - вершинная часть правой лопасти эпандрия и правый сурстиль, сбоку; 5 - левая лопасть эпандрия и левый сурстиль, сбоку. Сокращения: cerc — церк; epand - эпандрий; goncx apod — гонококсальная аподема; hypd — гипандрий; lft sur — левый сурстиль; rt sur — правый сурстиль. Масштаб: 0.1 мм. 
white pubescent, with scattered pale short setae and 1 longer subapical seta (considerably shorter than palpus).

Thorax black, prothoracic sclerites (including postpronotal lobe) and mesonotum greyish pollinose, entire mesopleuron shiny (small spot of tomentosity on lower part of katepisternum and meron). Postpronotal lobe large, elongate oval, lack- ing prominent setae, with scattered minute setulae. Mesonotum with 1 black, moderately long, spine-like notopleural and 2 similar, wide apart scutellars; acrostichals minute, arranged in 1-2 rows, prominent on presutural area only; dorsocentrals uniserial, minute, 1 prescutellar pair moderately long, spine-like, nearly as long as scutellars.

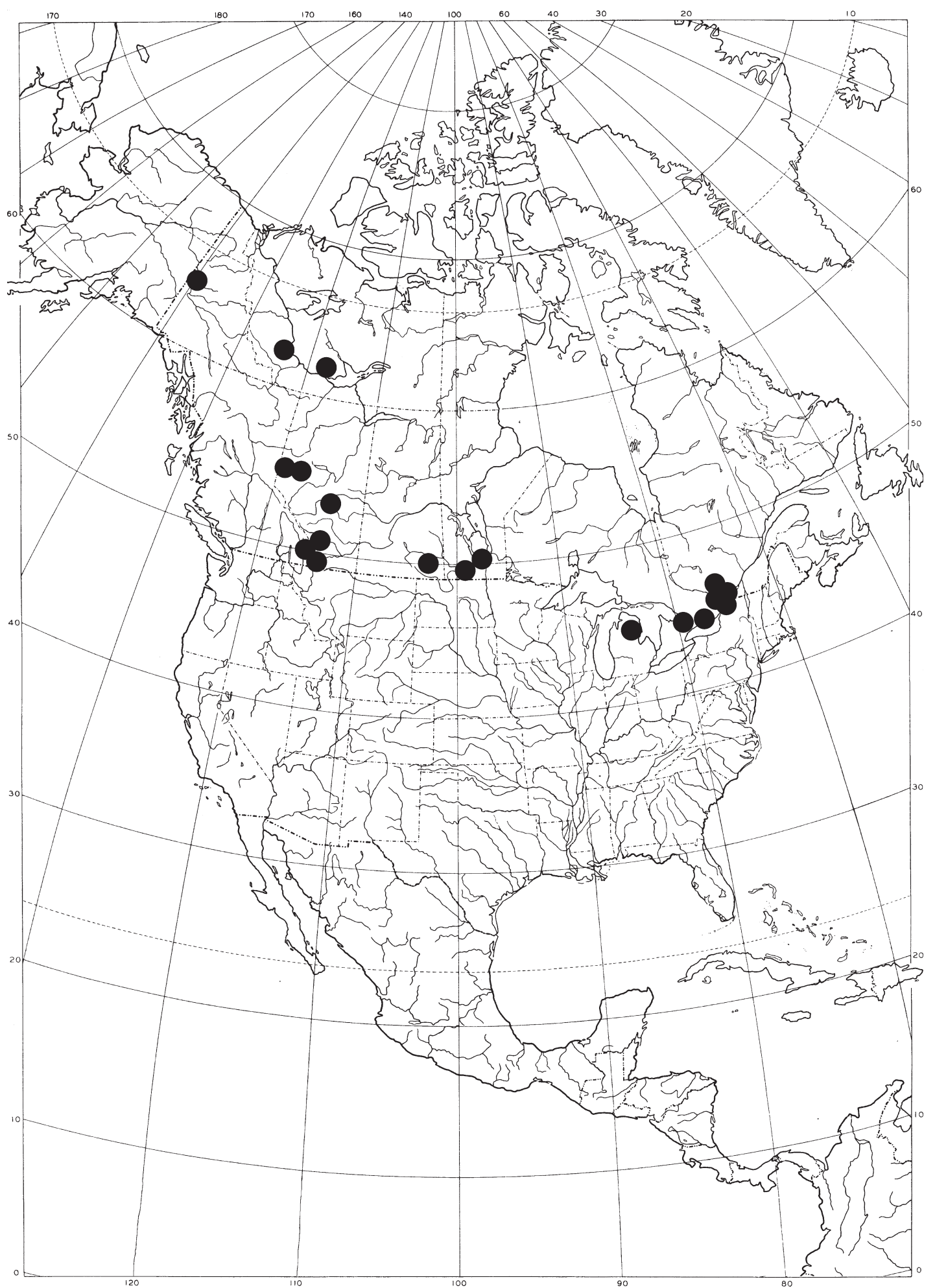

Fig. 6. Distribution of Tachypeza cummingi sp. $\mathbf{n}$. in the Nearctic Realm.

Рис. 6. Распространение Tachypeza cummingi sp. n. в Неарктическом царстве. 
Legs with fore coxa yellow, mid and hind coxae brownish (except yellowish apex); trochanters of all legs yellow; fore femur largely brownish yellow, paler ventrally, with brown rounded ventral spot near base, mid and hind femora brownish (somewhat paler closer to apex); tibiae brownish (except brownish yellow extreme base); fore and mid tarsomere 5 brown, otherwise fore and mid tarsi yellowish to brownish yellow, hind tarsus largely brownish, hind basitarsus yellow on basal $2 / 3$. Coxae clothed in pale unmodified setae of different lengths; fore coxa whitish pollinose anteriorly. Trochanters with unmodified setation. Fore femur strongly thickened, with rows of minute anteroventral and posteroventral setulae becoming slightly longer toward base. Fore tibia somewhat spindle-shaped, with hardly prominent spinulelike setae ventrally. Fore basitarsus with spinule-like setulae ventrally. Mid femur slender, with small depression near base ventrally, bearing rows of anteroventral and posteroventral spinule-like dark setulae beyond depression, 4-5 strong moderately long setae before depression (near extreme base of femur) and some spinule-like setulae on subapical face posteriorly. Mid tibia with shallow elongate ventral subapical depression bordered with black spinules, hardly prominent ventral spinules before depression, lacking apical projection. Hind femur slender, lacking prominent setae. Hind tibia unmodified, lacking prominent setae. Tarsomeres of mid and hind legs unmodified.

Wing (Fig. 1) normally developed, rounded at apex, with unmodified venation; largely brownish infuscate, with hyaline band near base. One minute costal seta present. Vein $\mathrm{R}_{2+3}$ straight. Veins $\mathrm{R}_{4+5}$ and $\mathrm{M}_{1+2}$ convergent near wing-apex. Anal vein and $\mathrm{CuA}_{2}$ absent (subsequently anal cell absent). Crossveins $\mathrm{r}-\mathrm{m}$ and bm-cu broadly separated. Cell $\mathrm{r} 1$ somewhat narrower than cell $\mathrm{r} 2+3$. Calypter brown, with pale brown cilia. Halter with yellow knob and brownish yellow stem.

Abdomen black brown, with scattered short setulae (mostly on sternites), pregenital segments with longer posteromarginal setae; tergites viewed dorsally shiny along midline, faintly greyish pollinose laterally. Tergite 8 and sternite 8 entirely fused, segment 8 ring-like. Terminalia (Figs $3-5$ ) moderately large, subglobular, blackish brown. Right cercus (Fig. 3) digitiform, rather long, rounded apically, covered with short setae; left cercus nearly 1.5 time shorter than right cercus, broadened on apical part, covered with short setae. Right epandrial lamella without ventral lobe, with 4 subapical spines on inner side; right surstylus (Fig. 4) separated from epandrial lamella, weakly sclerotised apically, with several setae of different lengths ventrally. Left epandrial lamella (Fig. 5) small, rather subtriangular (without apodeme), with broadly rounded apex, covered with setulae and with 2 moderately long setae on apical part; left surstylus separated from epandrial lamella, rather large, nearly as large as left epandrial lamella without apodeme, with short pointed internal projection, with short setae. Hypandrium humped, without setae.

FEMALE. Fore femur without brown rounded ventral spot near base. Mid femur lacking depression on basal part, bearing rows of anteroventral and posteroventral spinule-like setae becoming slightly longer toward base of femur and ending with 2 long brownish yellow to yellow setae, with unmodified setulae on subapical face posteriorly. Mid tibia without subapical depression. Cercus slender, brown, with minute setulae.

ETYMOLOGY. The new species is named in honour of the Canadian dipterist Jeffrey M. Cumming (Ottawa) in recognition of his contribution to the knowledge of the Diptera, especially empidoids.

REMARKS. Within the key to Tachypeza of North America [Melander, 1928] T. cummingi sp.n. would run to $T$. binotata Melander, 1928 and T. humeralis Melander, 1928. However, in both these species the fore femur of the male has two black spots (vs. one in the new species). The relationships of T. cummingi sp.n. with other Nearctic species of Tachypeza are unclear. Outside the Nearctic, the new species is most closely related to $T$. vietnamensis Grootaert et Shamshev, 2009 known only from mountains of northwest Vietnam [Grootaert, Shamshev, 2009]. Both species share weakly sclerotised, somewhat sculptured apical part of the right surstylus of the male genitalia.

DISTRIBUTION. NEARCTIC: Canada (Alberta, Manitoba, Ontario, Northwest Territories, Saskatchewan, Yukon), USA (Michigan) (Fig. 6).

HABITAT AND SEASONAL OCCURRENCE. According to label data the new species occurs on trunks of Populus, from the middle of May till the beginning of July.

\section{Tachypeza sachem (Melander), comb.n.}

Tachydromia sachem Melander, 1928: 283. Type locality: Turrialba (Costa Rica)

MATERIAL EXAMINED COSTA RICA: 19 , Monteverde, 15.02-15.03.1986, A. Forsyth (CNC). 1 + 2 km E Santa Elena, $1540 \mathrm{~m}, 11-13.06 .2000$, E. Fisher (Monty's station), CD 5086 (CNC) [SA-2].

DISTRIBUTION. NEOTROPICAL: Costa Rica.

REMARKS. Melander [1928] described T. sachem after a single female. We have not seen the holotype but the original description is quite detailed to be sure that this distinctive species is correctly recognised. The male of $T$. sachem remains unknown, however, provisionally, this species could be associated with the $T$. luang complex sharing with its scale-like silvery setae on lower part of the occiput and a curiously long black subapical seta on the palpus. It should be noted that $T$. sachem is unique among species of Tachypeza of the world in having partly yellow thorax (postpronotal lobes yellow). Currently, T. sachem is the only species of Tachypeza known from the Neotropical Realm.

\section{Check-list of Tachypeza of the world}

\section{Tachypeza Meigen, 1830}

Tachypeza Meigen, 1830: 341. Type species: Tachydromia nervosa Meigen, 1822: 72 (designated by Rondani, 1856: 147) [= Tachydromia nubila Meigen, 1804].

= Cormodromia: Zetterstedt, 1838: 545, MS name.

annamensis (Grootaert et Shamshev, 2009): 36, figs. 4-6 (Tachydromia). Type locality: Dak Lak Province, Chuo Yang Sin NP c. 50 km S. Buôn Mê Thuot, Krong K'Mar 590-840 m, rain forest near river (Vietnam). ORIENTAL: Vietnam. Comb.n.

annularis Melander, 1928: 274. Type localities: "Fieldbrook and Santa Cruz Mountains, California; Mount Constitution, Washington" (USA). NEARCTIC: USA (California, Washington).

australiensis (Grootaert et Shamshev, 2011): 104, fig. 1 (Tachydromia). Type locality: New South Wales, Wentworth Falls, Jamison Ck., cascades (Australia). AUSTRALASIAN: Australia (New South Wales). Comb.n.

bickeli (Grootaert et Shamshev, 2011): 105, fig. 2 (Tachydromia). Type locality: New South Wales, Fenwicks Ck, Doyles Riv. (Australia). AUSTRALASIAN: Australia (New South Wales). Comb.n.

binotata Melander, 1928: 275. Type localities: "Pullman, Washington; Sacramento, California” (USA). NEARCTIC: USA (California, Washington). 
brachialis (Melander, 1902): 242 (in key), 243 (Tachydromia). Type locality: Boonton, N.J. (USA). NEARCTIC: Canada (Ontario); USA (New Hampshire, New Jersey, Virginia).

clavipes Loew, 1864: 86. Type locality: Illinois (USA). NEARCTIC: USA (Illinois, Maryland, New Jersey, Pennsylvania).

corticalis (Melander, 1902): 342 (in key), 343 (Tachydromia). Type locality: Cloudcroft, New Mexico (USA). NEARCTIC: Canada (British Columbia); USA (California, Idaho, Montana, New Mexico, Washington, Wyoming).

corticola (Grootaert et Shamshev, 2011): 108, fig. 4a-d (Tachydromia). Type locality: Queensland, Ravensbourne NP, under bark Eucalyptus saligna (Australia). AUSTRALASIAN: Australia (New South Wales, Queensland). Comb.n.

cummingi Shamshev et Grootaert, 2018: 428-431, figs 1-5. Type locality: Ottawa, Ontario (Canada). NEARCTIC: Canada (Alberta, Manitoba, Ontario, Northwest Territories, Saskatchewan, Yukon); USA (Michigan). Sp.n.

discifera Melander, 1928: 273. Type localities: "Powell Co, Montana; Moscow, Idaho" (USA). NEARCTIC: Canada (Alberta, British Columbia), USA (Montana, Idaho).

distans Melander, 1928: 273. Type locality: Kamiac Butte, Washington (USA). NEARCTIC: USA (Washington).

dolorosa Melander, 1928: 275. Type locality: Cloudcroft, New Mexico (USA). NEARCTIC: USA (New Mexico). =rapax Loew: Melander, 1902: 343 .

excisa Melander, 1928: 274. Type locality: Ithaca, New York (USA). NEARCTIC: Canada (Quebec), USA (New York).

fenestrata (Say, 1823): 95 (Sicus). Type localities: "the middle states" (USA). NEARCTIC: Canada (New Brunswick), USA (Illinois, Maine, Missouri, Virginia, Wisconsin). =similis (Walker, 1849): 506 (Tachydromia). Type locality: St. Martin's Falls, Albany River, Hudson's Bay (Canada). [Smith, 1971: 366 (holotype data)] =rapax Loew, 1864: 85. Type locality: Illinois (USA).

fennica Tuomikoski, 1932, figs 3, 5. Type localities: "Ilomantsi, Jyväskylä" (Finland). PALAEARCTIC: Europe: Austria, Czech Republic, Estonia, Finland, Germany, Great Britain, Hungary, Latvia, Norway, Romania, Slovakia, Sweden, Switzerland, Ukraine; Russia (Murmanskaya Prov., Karelia, Leningradskaya, Moskovskaya, Sverdlovskaya Provinces); East Asia: Japan.

fuscipennis (Fallén, 1815): 14 (Tachydromia). Type locality: "Scania" [= Skåne] (Sweden). PALAEARCTIC: Europe: Austria, Croatia, Czech Republic, Denmark, Estonia, Finland, France, Germany, Great Britain, Hungary, Latvia, Norway, Slovakia, Sweden, Switzerland, Ukraine; Russia (European part: Leningradskaya, Moskovskaya, Ryazanskaya, Voronezhskaya Provinces, Krasnodarskiy Territory, Adygea, Kabardino-Balkaria; Eastern Siberia: Krasnoyarskiy Territory); West Asia: Azerbaijan; East Asia: Mongolia. =fusipennis: Schiner, 1860: 93, error.

heeri Zetterstedt, 1838: 547. Type locality: "Lapponia" (Finland or Sweden) (by lectotype designation). [Chvála, 1971: 9 (lectotype designation)]. PALAEARCTIC: Europe: Czech Republic, Estonia, Finland, Great Britain, Latvia, Norway, Slovakia, Sweden, Ukraine; Russia (European part: Murmanskaya Province, Karelia, Nenets, Leningradskaya, Moskovskaya, Voronezhskaya Provinces; Western Siberia: Yamalo-Nenets, Khanty-Mansi; Eastern Siberia: Irkutskaya Prov., Yakutia; Far East: Amurskaya Province, Primorskiy Territory); East Asia: Japan. =punctipes Zetterstedt, 1838: 547, nomen nudum. [Chvá- la, 1971: 9 (notes)].

hispanica Chvála, 1981: 168, fig. 26. Type locality: Almeria, Alhama, 5 km W, 200-500 m (Spain). PALAEARCTIC: Spain.

humeralis Melander, 1928: 276. Type locality: Washington, D.C. (USA). NEARCTIC: Canada (Ontario, Quebec), USA (D.C.).

incisa (Brunetti, 1913): 41 (Platypalpus). Type locality: Simla, W Himalayas (India). ORIENTAL: India.

inusta (Melander, 1902): 224 (in key), 226 (Tachydromia). Type localities: "Juliaetta, Moscow and Craig's Mt., Idaho; Magdalena Mts., N. Mexico" (USA). NEARCTIC: USA (California, Colorado, Idaho, New Mexico, Oregon, Washington).

luang (Shamshev et Grootaert, 2005): 115, figs 12-15 (Tachydromia). Type locality: Loyang mangrove, tree trunk (Singapore). ORIENTAL: Singapore, Thailand. Comb.n.

malaysiensis (Shamshev et Grootaert, 2009): 251, figs 1-3 (Tachydromia). Type locality: Pahang, Tanah Rata, 1460 m (Malaysia). ORIENTAL: Malaysia. Comb.n.

nigra Yang et Yang, 1997: 1470, fig. 3 (female). Type locality: Hubei, Xingshan, 1300 m (China). ORIENTAL: China (Hubei).

nowendociensis (Grootaert et Shamshev, 2011): 109, fig. 5 (Tachydromia). Type locality: New South Wales, $10 \mathrm{~km}$ SE Nowendoc, $850 \mathrm{~m}$, on tree trunk (Australia). AUSTRALASIAN: Australia (New South Wales). Comb.n.

nubila (Meigen, 1804): 239. Type locality: not given (?Europe). PALAEARCTIC: Europe: Austria, Belgium, Croatia, Czech Republic, Denmark, Estonia, Finland, France (including Corsica), Germany, Great Britain, Hungary, Ireland, Latvia, Lithuania, Norway, Poland, Romania, Slovakia, Spain, Sweden, Switzerland, the Netherlands, Turkey, Ukraine; Russia (European part: Karelia, Leningradskaya, Tverskaya, Moskovskaya, Ryazanskaya, Voronezhskaya, Belgorodskaya, Samarskaya Provinces, Permskiy Territory, Sverdlovskaya Province, Crimea, Krasnodarskiy Territory, Adygea, Kabardino-Balkaria; Western Siberia: Khanty-Mansi, Altayskiy Territory; Eastern Siberia: Krasnoyarskiy Territory); West Asia: Azerbaijan.

=nervosa (Meigen, 1822): 72 (Tachydromia). Type locality: "Oesterreich" (?Austria).

=tibialis (Macquart, 1823): 154 (Tachydromia). Type locality: not given (NW France).

=nova Siebke, 1877: 25 (as var. of nervosa Meigen, nec Siebke, 1877). Type locality: "ad Ormem” (Norway). =subnubila Raffone, 2002: 40, fig. 4. Type locality: Parma, Riserva naturale Guadine-Pradaccio (Italy). [Barták, Kubík, 2018: 476].

ocellata (Shamshev et Grootaert, 2008): 29, figs 10-12, 27, 31 (Tachydromia). Type locality: Loei prov., Phu Ruea NP Subhnonghin $17^{\circ} 28.772^{\prime} \mathrm{N} 101^{\circ} 21.308^{\prime} \mathrm{E} 860 \mathrm{~m}$ (Thailand). ORIENTAL: Thailand. Comb.n.

pahangiensis (Shamshev et Grootaert, 2009): 253 (female, Tachydromia). Type locality: Pahang, Brinchang (Malaysia). ORIENTAL: Malaysia. Comb.n.

phanensis (Shamshev et Grootaert, 2008): 23, figs 1-3, 24 (Tachydromia). Type locality: Chaiyaphum prov., $\mathrm{Pa}$ Hin Ngam NP Tung Dok Grajeaw, 15³8.208'N $101^{\circ} 23.556{ }^{\prime} \mathrm{E}, 720 \mathrm{~m}$ (Thailand). ORIENTAL: Thailand. Comb.n.

phu (Shamshev et Grootaert, 2008): 25, figs 4-6, 25 (Tachydromia). Type locality: Loei prov., Phu Ruea NP office, $17^{\circ} 28.805^{\prime} \mathrm{N} 101^{\circ} 21.242^{\prime} \mathrm{E}, 870 \mathrm{~m}$ (Thailand). ORIEN- 
TAL: Thailand. Comb.n.

portaecola (Walker, 1849): 506 (Tachydromia). Type locality: St. Martin's Falls, Albany River, Hudson's Bay (Canada). NEARCTIC: Canada (New Brunswick). [Smith, 1971: 365, text-fig. 15 (holotype data)].

postica (Walker, 1857): 149 (Tachydromia). Type locality: "United States" (USA). NEARCTIC: USA (D.C., Kansas, New Mexico). [Smith, 1971: 366, pl. 3, fig. 6 (holotype data)].

pruinosa Coquillett, 1903: 267. Type locality: Atherton, Missouri (USA). NEARCTIC: USA (Missouri).

rostrata Loew, 1864: 248. Type locality: New Hampshire(USA). NEARCTIC: USA (Maine, New Hampshire, Virginia).

sachem Melander, 1928: 283 (Tachydromia). Type locality: Turrialba (Costa Rica). NEOTROPICAL: Costa Rica. Comb.n.

sericeipalpis Frey in Lundström et Frey, 1913: 10. Type locality: "Mikulkin" [= cape Mikulkin (Kanin Peninsula), $67^{\circ} 482 \mathrm{~N} 46^{\circ} 412 \mathrm{E}$ ], Nenets Autonomous Okrug (Russia). PALAEARCTIC: Russia (European part: Murmanskaya Province, Nenets; Eastern Siberia: Yakutia; Far East: Chukotka).

=dilutata Frey, 1915: 3, 14 (as var. of sericeipalpis Frey). Type locality: "Lena-Mündung, Chara-Ullach-Gebirge, am Ketalach-See [= Kharaulakhskiy Ridge near mouth of the Lena River, $\left.\sim 71^{\circ} 442 \mathrm{~N} 128^{\circ} 162 \mathrm{E}\right]$, Yakutia (Russia).

stuckenbergi (Shamshev et Grootaert, 2010): 213, figs 5-8, 12 (Tachydromia). Type locality: District Masindi, Budongo Forest, near Sonso, $1^{\circ} 45^{\prime} \mathrm{N} 31^{\circ} 35^{\prime} \mathrm{W}$, Teclea nobilis, swamp forest (Uganda). [Grootaert et al., 2015: 167, fig. 1 (female)]. AFROTROPICAL: Uganda. Comb.n.

tanaisense Kovalev in Chvála, 1975: 61 (in key); Kovalev, 1976: 460. Type locality: mouth of Don River, village

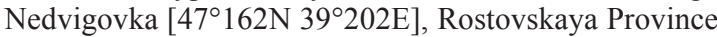
(Russia). PALAEARCTIC: Czech Republic, Russia, Ukraine.

tigeri (Shamshev et Grootaert, 2008): 27, figs 7-9, 26 (Tachydromia). Type locality: Chiang Mai Province, Doi Inthanon NP summit marsh $18^{\circ} 35.361^{\prime} \mathrm{N} 98^{\circ} 29.157^{\prime} \mathrm{E} 2500$ m (Thailand). ORIENTAL: Thailand. Comb.n.

truncorum (Fallén, 1815). Type locality: Scania [= Skåne] (Sweden). PALAEARCTIC: Europe: Austria, Czech Republic, Denmark, Estonia, Finland, Germany, Great Britain, Italy, Latvia, Lithuania, Norway, Romania, Slovakia, Slovenia, Sweden, Switzerland, Ukraine; Russia (European part: Arkhangelskaya Province, Karelia, Leningradskaya, Moskovskaya, Ryazanskaya, Smolenskaya, Sverdlovskaya Provinces; Western Siberia: Altayskiy Territory; Eastern Siberia: Irkutskaya Province); East Asia: Mongolia.

vietnamensis Grootaert et Shamshev, 2009: 39, figs 7-9. Type locality: Lao Cai Province, Sa Pa, Sin Chai, c. 1900 m (Vietnam). ORIENTAL: Vietnam.

vriesi Grootaert et Shamshev, 2009: 41, figs 10-12. Type locality: Lao Cai Province, Sa Pa, Sin Chai, c. 1900 m (Vietnam). ORIENTAL: Vietnam.

winthemi Zetterstedt, 1838: 548. Type locality: Lycksele (Sweden) (by lectotype designation). [Chvála, 1971: 25 (lectotype designation)]. PALAEARCTIC: Europe: Finland, Norway, Sweden; Russia (European part: Murmanskaya Province, Karelia, Nenets; Eastern Siberia: Yakutia; Far East: Kamchatskiy Territory). NEARCTIC: Canada (Alberta, British Columbia, Manitoba, Newfoundland and Labrador, Northwest Territories, Quebec); USA (Massachusetts, Montana, New Hampshire). yinyang Papp et Földvári, 2002: 352, figs 6-10. Type locality: K-Mecsek Landscape Protected Area: Óbánya, Óbányai-völgy, over the brook (Hungary). PALAEARCTIC: Hungary, Russia (Adygea, Krasnodarskiy Territory).

ACKNOWLEDGEMENTS. The authors are indebted to Bradley J. Sinclair and Jeffrey M. Cumming (CNC, Ottawa), Christophe Daugeron (MNHN, Paris), Rui Andrade (Portugal) and Ana Gonçalves (Portugal) for the loan of the material. Fedor Konstantinov (St. Petersburg State University, St. Petersburg, Russia) kindly provided the equipment and software for making digital images. Vladimir Neimorovets (All-Russian Institute of Plant Protection, St. Petersburg-Pushkin, Russia) kindly produced a photo of the habitus of the new species. The study of Igor Shamshev was performed within the frames of the Russian State Research Project no. AAAA-A17-117030310210 3 and supported by the Russian Foundation for Basic Research (grant no. 18-04-00354A) and the Presidium RAS program no.41 "Biodiversity of natural systems and biological sources of Russia". Also, Igor Shamshev acknowledges the Belgian Science Policy for supporting his stay in RBINS.

\section{References}

Andrade R. 2011. Observations on the behaviour of Ariasella lusitanica, Grootaert et al., 2009 (Diptera, Hybotidae, Tachydromiinae) from Portugal // Bulletin de la Société royale belge d'Entomologie, S.R.B.E./K.B.V.E. Vol.147. P.241-250.

Arias J. 1919. Descripción preliminar de un nuevo Émpido de España // Boletín de la Real Sociedad Española de Historia Natural. Vol.19. P.479-481.

Barták M., Kubík Š., 2018. Hybotidae (Diptera) from Turkey, with descriptions of seven new species // Zootaxa. Vol.4410. P.453-482.

Brunetti E. 1913. New Indian Empididae// Records of the Indian Museum. Vol.9. P.11-45.

Chvála M. 1970. Revision of Palaearctic species of the genus Tachydromia Meig. (= Tachista Loew) (Diptera, Empididae) // Acta Entomologica Musei Nationalis Pragae. Vol.38[1969]. P.415-524.

Chvála M. 1971. A revision of the Scandinavian Tachydromiinae (Dipt., Empididae) described by J.W. Zetterstedt // Entomologica Scandinavica. Vol.2. P.1-28.

Chvála M. 1975a. The Tachydromiinae (Dipt. Empididae) of Fennoscandia and Denmark // Fauna Entomologica Scandinavica. Vol.3. P.1-336.

Chvála M. 1975b. A revision of the Palaearctic Tachydromiine genus Dysaletria Loew (Diptera, Empididae) // Věstník československé Společnosti zoologické. Vol.39. P.167-172.

Chvála M. 1975c. Distribution of the genus Tachypeza Meig. (Diptera, Empididae) in Czechoslovakia // Folia Facultatis Scientiarum Naturalium Universitatis Purkynianae Brunensis. Biologia. Vol.43[1974]. P.57-61.

Chvála M. 1981. Empididae (Insecta: Diptera) from southern Spain, with descriptions of twenty new species and notes on Spanish fauna // Steenstrupia. Vol.7. P.113-177.

Collin J.E. 1961. Empididae // British Flies. Vol.6. Cambridge: University Press. $782 \mathrm{pp}$.

Coquillett D.W. 1903. The genera of the dipterous family Empididae, with notes and new species // Proceedings of the Entomological Society of Washington. Vol.5. P.245-272.

Cumming J.M. 2007. Baeodromia, a new genus of tachydromiine fly from the New World (Diptera: Empidoidea; Hybotidae) // The Journal of the Entomological Society of Ontario. Vol.137. P.41-49.

Cumming J.M., Sinclair B.J. 2009. Empididae (dance flies, balloon flies, predaceous flies) // Brown B.V., Borkent A., Cumming J.M., Wood D.M., Zumbado M. (eds.). Manual of Central American Diptera. Vol.1. Ottawa: NRC Research Press. P.653-670.

Fallén C.F 1815. Empididae Sveciae. Lundae [= Lund]. 16 pp.

Freitas-Silva R.A.P., Ale-Rocha R. 2013. A new apterous species of Platypalpus Macquart (Diptera: Hybotidae, Tachydromiinae) from Ecuador // Zootaxa. Vol.3636. P.590-596.

Frey R. 1915. Diptera-Brachycera aus den arktischen Küstengeg- 
enden Sibiriens. Résultats scientifiques de l'expédition polaire Russe en 1900-1903, sous la direction du Baron E. Toll, Section E: Zoologie. Volume II, livr. 10 // Zapiski Rossiyskoy Akademii Nauk po Fiziko-Matematicheskomu Otdeleniyu (Transactions of the Russian Academy of Sciences for Physical and Mathematical Branch). Vol.29. S.1-35.

Gil J. 1923. Estudio de un nuevo Taquidromino de España // Boletín de la Real Sociedad Española de Historia Natural. Vol.23. P.150-154.

Gil J. 1936. Una nueva especie del género Ariasella Gil, con breves consideraciónes sobre la reduccion del tórax en los Taquidrominos ápteros // Eos (Revista Española de Entomologia). Vol.11. P.191-201.

Grootaert P., Chvála M. 1992. Monograph of the genus Platypalpus (Diptera: Empidoidea, Hybotidae) of the Mediterranean region and the Canary Islands // Acta Universitatis Carolinae Biologica. Vol.36. P.3-226.

Grootaert P., Shamshev I. 2008. Notes on the halobiont genus Chersodromia (Diptera: Hybotidae) from Tunisia with the description of a new brachypterous species and notes on brachyptery in empidoids // Bulletin de la Société royale belge d'Entomologie, S.R.B.E./K.B.V.E. Vol.144. P.57-63.

Grootaert P., Shamshev I. 2009. First records of Tachydromia Meigen and Tachypeza Meigen (Diptera: Hybotidae) from Viet Nam, with descriptions of four new species // Zootaxa. Vol.2249. P.33-43.

Grootaert P., Shamshev I. 2011. The genus Tachydromia Meigen (Diptera: Hybotidae) from Australia// Records of the Australian Museum. Vol.63. P.103-112.

Grootaert P., Shamshev I.V. 2012. The fast-running flies (Diptera Hybotidae, Tachydromiinae) of Singapore and adjacent regions // European Journal of Taxonomy. Vol.5. P.1-162.

Grootaert P., Shamshev I., Andrade R. 2009. Description of a new brachypterous Ariasella Gil (Diptera, Hybotidae, Tachydromiinae) from Portugal // Bulletin de la Société royale belge d'Entomologie, S.R.B.E./K.B.V.E. Vol.145. P.45-48.

Grootaert P., Shamshev I., Goudeseune L., 2015. New data on the genus Tachydromia Meigen from Uganda, with description of a new species (Diptera: Hybotidae) // Bulletin de la Société royale belge d'Entomologie, S.R.B.E./K.B.V.E. Vol.151. P.166-171.

Kovalev V.G., 1976. [Tachypeza tanaisense V. Kovalev in Chvála, 1975, a peculiar dance fly (Diptera, Empididae)] // Zoologicheskiy Zhurnal. Vol.55. P.460-462. [in Russian, with English summary].

Loew H. 1864. Diptera Americae septentrionalis indigena. Centuria Quinta // Berliner Entomologische Zeitscrift. Bd.8 S.49-104.

Lundström C., Frey R. 1913. Beitrag zur Kenntnis der Dipterenfaun des nördl. europäischen Russlands // Acta Societatis pro Fauna et Flora Fennica. Vol.37. P.1-20.

Macquart J., 1823. Monographie des Insectes Diptères de la famille des Empides, observés dans le nord-ouest de la France // Mémoires de la Société (Royale) des Sciences, de l'Agriculture et des Arts á Lille. Vol.1822. P.137-165.

Meigen J.W. 1804. Klassifikation und Beschreibung der europäischen zweiflügligen Insekten (Diptera Linn.). Erster Band. Abt. II // Braunschweig [= Brunswick]: Reichard. vi + pp. 153-314.

Meigen J.W. 1822. Systematische Beschreibung der bekannten europäischen zweiflügeligen Insekten. Dritter Theil // SchultzWundermann, Hamm. x +416 pp.

Meigen J.W. 1830. Systematische Beschreibung der bekannten europäischen zweiflügeligen Insekten. Sechster Theil // Schulz, Hamm. xi $+401+[3]$ pp.

Melander A.L. 1902. Monograph of the North American Empididae. Part I // Transactions of the American Entomological Society. Vol.28. P.195-367, 5 pls.

Melander A.L. 1928. Diptera, Fam. Empididae // Wytsman P. (Ed.) Genera Insectorum. Fasc.185(1927). Bruxelles: Louis DesmetVerteneuil. P.1-434.

Moulton J.K., Wiegmann B.M. 2007. The phylogenetic relationships of flies in the superfamily Empidoidea (Insecta: Diptera) // Molecular Phylogenetics and Evolution. Vol.43. P.701-713.

Nagy Z.T., Sonet G., Mortelmans J., Vandewynkel C., Grootaert P. 2013. Using DNA barcodes for assessing diversity in the family Hybotidae (Diptera, Empidoidea) // Nagy Z.T., Backeljau T., De Meyer M., Jordaens K. (Eds). DNA barcoding: a practical tool for fundamental and applied biodiversity research // ZooKeys. Vol.365. P.263-278

Papp L., Földvári M. 2002. A new genus and three new species of Hybotidae with new records of the Hungarian Empidoidea
(Diptera) // Acta Zoologica Academiae Scientiarum Hungaricae. Vol.47. P.349-361.

Plant A.R., Deeming J.C. 2006. An apterous species of Tachydromia Meigen, 1803 (Diptera: Hybotidae) from Italy // An International Journal of Dipterological Research. Vol.17. P.13-16.

Raffone G. 2002. Su Alcuni Ditteri della Riserva Naturale di Guadine Pradaccio (Parma) (Insecta Diptera Hybotidae) // Quaderno di Studi e Notizie di Storia Naturale della Romagna. Vol.17. P.35-42.

Rondani C. 1856. Dipterologiae Italicae prodromus. Vol. I. Genera Italica Genera italica ordinis Dipterorum ordinatim disposita et distincta et in familias et stirpes aggregata // A. Stoschi, Parmae [= Parma]. $226+[2] \mathrm{pp}$.

Say T. 1823. Descriptions of dipterous insects of the United States // Journal of the Academy of Natural Sciences of Philadelphia. Vol.3. P.9-54, 73-104.

Schiner J.R. 1860. Fauna Austriaca. Theil 1. Heft 2 (part)//C. Gerold's Sohn, Wien [= Vienna]. S.73-184. Pl.1.

Séguy E. 1941. Étude sur un nouveau Corynétine des Pyrénées (Dipt., Empididae) // Bulletin de la Société entmologique de France. Vol.46. P.4-6.

Shamshev I.V. 1994a. [Revision of the types of species of the genus Tachydromia Meigen (Diptera, Empidoidea, Hybotidae), described by R. Frey and J. Collin from the Siberia and Far East] // Vestnik Zoologii. Vol.2. P.33-38. [in Russian, with English summary].

Shamshev I.V. 1994b. Tachydromia rossica sp. n. (Diptera, Hybotidae) a wingless species from the eastern Palaearctic // Russian Entomological Journal. Vol.3. P.163-164.

Shamshev I., Grootaert P. 2005. The genus Tachydromia Meigen (Diptera: Hybotidae) from South East Asia, with the description of three new species // Studia Dipterologica. Bd.12. S.109-117.

Shamshev I., Grootaert P. 2008. New and little-known species of the genus Tachydromia Meigen (Diptera, Hybotidae) from Thailand // Zootaxa. Vol.1830. P.21-36.

Shamshev I., Grootaert P. 2009. Two new species of the genus Tachydromia Meigen (Diptera: Hybotidae) from Malaysia // Raffles Bulletin of Zoology. Vol.57. P.251-254.

Shamshev I., Grootaert P. 2010. The genus Tachydromia Meigen (Diptera: Hybotidae) from the Afrotropics // African Invertebrates. Vol.51. P.31-46.

Shamshev I., Grootaert P. 2012. Proposed change in status of the Nearctic genus Charadrodromia Melander (Diptera: Hybotidae, Tachydromiinae), with description of four new species // Zootaxa. Vol.3525. P.35-50.

Siebke J.H.S. 1877. Catalogum Dipterorum Continentem. Schneider J.S. (Ed.), Enumeratio insectorum Norvegicorum. Fasciculum IV // A.W. Broegger, Christianiae [= Oslo]. xiv +255 pp.

Sinclair B.J., Cumming J.M. 2006. The morphology, higher-level phylogeny and classification of the Empidoidea (Diptera) // Zootaxa. Vol.1180. P.1-170.

Smith K.G.V. 1971. A revision of Francis Walker's types of North American Empididae (Diptera) // Bulletin of the British Museum (Natural History) Entomology. Vol.26. P.347-370, pls 1-3.

Stark A. 1996. Eine neue brachyptere Tachydromia aus Deutschland und Diskussion ihres Indikatorwertes fur alte Diinengebiete im Binnenland (Diptera, Empidoidea, Hybotidae) // Studia dipterologica. Bd.3. S.300-310.

Stark A., Doczkal D. 2017. 7.1. Tachydromia wendti spec. nov. (Diptera, Empidoidea, Hybotidae) from riverbeds at the Northern slope of the Alps and its forelands in Germany // Mauritiana (Altenburg). Vol.34. P.481-498.

Tuomikoski R. 1932. 1932. Zwei neue Empididen aus Finnland // Notulae Entomologicae. Vol.12. P.46-50.

Wahlberg E., Johanson K.A. 2018. Molecular phylogenetics reveals novel relationships within Empidoidea (Diptera) // Systematic Entomology. Vol.43. P.1-18.

Walker F. 1849. List of the specimens of dipterous insects in the collection of the British Museum. Part III // British Museum, London, pp. [3] + 485-687.

Walker F. 1857. Characters of undescribed Diptera in the collection of W. W. Saunders, Esq., F.R.S., \&c. [part] // Transactions of the Entomological Society of London (n.s.). Vol.4. P.119-153.

Zetterstedt J.W. 1838. Sectio tertia. Diptera. Dipterologis scandinaviae. amicis et popilaribus carissimus, pp. 477-868// Insecta Lapponica, Lipsiae [= Leipzig], vi + 1140 pp. 